\title{
PENGEMBANGAN RUMAH SEDERHANA SEHAT (RSH) MENJADI RUMAH SEDERHANA SEHAT BERWAWASAN LINGKUNGAN DI KABUPATEN MALANG
}

\author{
Ary Deddy Putranto \\ Jurusan Arsitektur/Fakultas Teknik Universitas Brawijaya \\ arydeddy@ub.ac.id
}

\begin{abstract}
ABSTRAK
Kebutuhan perumahan di perkotaan semakin meningkat. Untuk itu pemerintah melakukan upaya untuk memenuhi kebutuhan rumah bagi masyarakat berpenghasilan rendah dan terjangkau. Pemenuhan kebutuhan tersebut salah satunya dengan pengadaan Rumah Sederhana Sehat (RSH). Walaupun RSH diperuntukkan bagi masyarakat berpenghasilan rendah, tetapi RSH harus layak, terjangkau, memenuhi persyaratan kesehatan, keamanan dan kenyamanan serta berwawasan lingkungan.

Tujuan studi ini yaitu mendapatkan / memperoleh hubungan antar aspek-aspek kepuasan konsumen RSH yang berwawasan lingkungan serta mengetahui tingkat kepuasan pengembang dan konsumen terhadap RSH yang dikembangkan menjadi perumahan yang berwawasan lingkungan.

Metode yang digunakan untuk mengolah data pada studi ini meliputi Analisa Deskriptif, IPA \& Analisa Korelasi.

Hasil studi menunjukkan nilai jual RSH berwawasan lingkungan di bandingkan dengan RSH yang ada telah mengalami peningkatan nilai jual sebesar Rp. 3.090.389.,-. Hal tersebut dapat diketahui dari Rencana Anggaran Biaya (RAB) sebelum dan sesudah RSH, dikembangkan menjadi RSH yang berwawasan lingkungan. Besarnya nilai jual RSH yang ada (kondisi eksisting) sebesar Rp. 37.223.863,-. Sedangkan RSH berwawasan lingkungan memiliki nilai jual sebesar Rp. 40.314.253,-. Selain itu, tingkat keinginan konsumen terhadap RSH yang dikembangkan menjadi RSH yang berwawasan lingkungan yaitu $0,6 \%$ responden menyatakan kurang ingin; $24,4 \%$ menyatakan cukup ingin dan $75 \%$ menyatakan ingin.

Sebaiknya pengembang dalam memilih lokasi perumahan walaupun berada dipinggir kota, harus tetap mempertimbangkan lokasi perumahan dekat dengan sarana pendidikan dan kesehatan. Sedangkan mengenai Keamanan Lingkungan, Kenyamanan Lingkungan, Kepemilikan Rumah dan Kreatifitas Pemilik Terhadap Rumah, bisa dikatakan telah memuaskan konsumen, diharapkan pengembang dapat mempertahankan kepuasan konsumen pada aspek-aspek ini.
\end{abstract}

Kata Kunci : RSH, IPA, Berwawasan Lingkungan

\section{PENDAHULUAN}

\section{Latar Belakang}

Perkotaan dengan kompleksitas permasalahan yang ada, di tambah laju urbanisasi yang mencapai 4,4\% per tahun membuat kebutuhan perumahan di perkotaan semakin meningkat. Untuk itu pemerintah melakukan upaya untuk memenuhi kebutuhan rumah bagi masyarakat berpenghasilan rendah dan terjangkau.

Pemenuhan kebutuhan tersebut salah satunya dengan pengadaan Rumah Sederhana Sehat (RSH). Walaupun RSH diperuntukkan bagi masyarakat berpenghasilan rendah, tetapi RSH harus layak, terjangkau, memenuhi persyaratan kesehatan, keamanan dan kenyamanan serta berwawasan lingkungan. Akan tetapi pada kenyataannya kepuasan konsumen perumahan, terutama RSH masih bukan kewajiban pengembang untuk memenuhinya. Lokasi perumahan yang jauh dari keramaian, kualitas bangunan dibawah standar, jauh dari sarana pendidikan, sarana kesehatan dan sarana perbelanjaan, tidak adanya pagar bangunan, kurangnya taman, pohon peneduh dan sempitnya rumah RSH serta jauh dari kondisi perumahan yang berwawasan lingkungan. Kedudukan konsumen sangat lemah dan tidak 
jarang seperti di-fait accompli, yaitu konsumen dipaksa menerima keadaan yang ada oleh pengembang.

Menanggapi hal tersebut diatas, diperlukan adanya sebuah kajian yang menyeluruh tentang perencanaan Rumah Sederhana Sehat (RSH) yang tidak hanya sekedar memenuhi kebutuhan akan perumahan bagi masyarakat berpenghasilan rendah melainkan Rumah Sederhana Sehat (RSH) yang layak, terjangkau, memenuhi persyaratan kesehatan, keamanan dan kenyamanan, berkualitas, serta ramah terhadap lingkungan (berwawasan lingkungan) sebagai ikon pembangunan kota yang berkelanjutan.

\section{Batasan Masalah}

Untuk memfokuskan pembahasan pada studi ini, maka perlu dibatasi permasalahannya. Adapun batasan masalah yang diberikan adalah sebagai berikut:

1. Studi dilakukan di Kabupaten Malang.

2. Jenis perumahan yang dikembangkan menjadi perumahan yang berwawasan lingkungan adalah Rumah Sederhana Sehat (RSH).

3. Obyek RSH yang dijadikan penelitian yaitu Tambak Asri permai di Tajinan Malang, Singosari Residence, dan Mondoroko Regency.

4. Lingkup tipe rumah yang dijadikan sampel penelitian adalah rumah dengan tipe 36.

5. Tidak membahas secara detail konstruksi kawasan perumahan.

6. Tidak membahas analisa sosial masyarakat di sekitar lokasi perumahan.

\section{Rumusan Masalah}

Dari permasalahan di atas, maka pada studi ini dirumuskan sebagai berikut :

1. Bagaimana perancangan RSH yang berwawasan lingkungan?

2. Bagaimana tingkat keinginan konsumen terhadap RSH yang dikembangkan menjadi RSH yang berwawasan lingkungan?

3. Bagaimana tingkat keinginan pengembang terhadap RSH yang dikembangkan menjadi RSH yang berwawasan lingkungan?

\section{TINJAUAN PUSTAKA}

\section{Ketentuan Teknis Rumah Sederhana Sehat (RSH)}

Ketentuan Teknis Rumah Sederhana Sehat (RSH) - Rumah Tembok:

1. Persyaratan Kesehatan Rumah Tinggal:

Kondisi fisik, kimia dan biologis di dalam rumah memenuhi ketentuan Keputusan Menteri Kesehatan No. 829/MENKES/SK/VII/1999, menyangkut persyaratan bahan bangunan, komponen dan penataan ruang rumah, pencahayaan, kualitas udara, ventilasi, binatang penular penyakit, air, sarana penyimpanan makanan yang aman, limbah dan kepadatan hunian ruang tidur.

2. Pemilihan Lokasi

Tersedianya tanah yang cukup bagi pembangunan rumah, pada satu lingkungan yang memiliki kelengkapan prasarana lingkungan, utilitas umum dan fasilitas sosial. Apabila pembangunan perumahan dilakukan melalui industri perumahan di Lisiba dan Kasiba maka minimal 1000 unit untuk Lisiba dan 3000 unit untuk Kasiba.

3. Peraturan Daerah

Beberapa peraturan daerah yang perlu dipenuhi menyangkut:

a. Luas lahan efektif minimal antara $72 \mathrm{~m}^{2}$ sampai dengan $90 \mathrm{~m}^{2}$ khususnya dipersyaratkan di kawasan perkotaan bukan pusat kota,

b. Lebar muka kaveling minimal $6 \mathrm{~m}$ atau 7,5 $\mathrm{m}$,

c. Untuk mengantisipasi kebakaran panjang deretan kaveling maksimum $75 \mathrm{~m}$, kurang lebih 10 kapling dengan ukuran lebar kapling 7,5 m dan atau 12 kapling untuk lebar muka kapling dengan ukuran $6 \mathrm{~m}$,

d. Bagian kaveling yang tertutup bangunan rumah maksimum $60 \%$ dan luas kaveling atau sesuai Peraturan Daerah setempat, 
e. Koefisien lantai bangunan 1,2 .

4. Kebutuhan Dasar Minimal suatu Rumah

a. Atap yang rapat dan tidak bocor,

b. Lantai yang kering dan mudah dibersihkan,

c. Penyediaan air bersih yang cukup,

d. Pembuangan air kotor yang baik dan memenuhi persyaratan kesehatan,

e. Pencahayaan alami yang cukup,

f. Udara bersih yang cukup melalui pengaturan sirkulasi udara sesuai dengan kebutuhan.

5. Dari Segi Aktivitas Penghuni dan Kesehatan, dipergunakan norma:

a. Kebutuhan udara bersih didalam rumah $\pm 9 \mathrm{~m}^{3} /$ orang,

b. Kebutuhan pergantian udara $\pm 0,80 \mathrm{~m}^{3} /$ menit/orang,

c. Kebutuhan penerangan alam didalam kamar minimum 50 lux,

d. Kebutuhan penerangan buatan untuk seluruh rumah minimum $100 \mathrm{VA}$,

e. Kebutuhan air bersih \pm 100 liter/hari/orang.

Untuk pembuangan air kotor dipergunakan cara-cara yang memenuhi syarat-syarat kesehatan, antara lain tangki septik, sumuran (beerput), saluran pembuangan air kotor (riool). Yang disediakan melalui program perbaikan sarana dan prasarana lingkungan dari Pemerintah Daerah.

6. Rancangan Proses Pengembangan RSH:

a. Bangunan Rumah Inti Tumbuh (RIT-1) berukuran $21 \mathrm{~m}^{2}$ dengan ruangan- ruangan:

- Ruang inti berukuran 3,00 x 3,00 m²

- Ruang serba guna (tanpa dinding) berukuran 3,00 x 3,00 $\mathrm{m}^{2}$

- Kamar mandi + WC (tanpa atap) berukuran 1,50 x 1,20 $\mathrm{m}^{2}$

b. Pertumbuhan menjadi Rumah Sederhana Sehat (RsS-1) berukuran $28.8 \mathrm{~m}^{2}$ dengan ruangan:

- Dua Ruang tidur berukuran 3,00x3,00 m²

- Ruang Servis/pertumbuhan berukuran 2,50 x 3,00 m²

- Kamar mandi + WC berukuran 1,50 x 1,20 m²

c. Pertumbuhan menjadi Rumah Sederhana Sehat (RsS-2) berukuran $36 \mathrm{~m}^{2}$ dengan ruangan:

- Dua Ruang tidur berukuran 3,00 x 3,00 $\mathrm{m}^{2}$

- Ruang tidur anak berukuran $3,00 \times 3,00 \mathrm{~m}^{2}$

- Ruang tamu berukuran $2.50 \times 3.00 \mathrm{~m}^{2}$

- Ruang berukuran $3.00 \times 3.00 \mathrm{~m}^{2}$

- Kamar mandi + WC berukuran 1,50 x 1,20 m²

d. Konstruksi bangunan rumah:

- Pondasi konstruksi batu kali,

- Lantai konstruksi rabat beton,

- Dinding konstruksi pasangan conblock,

- Kusen pintu/jendela konstruksi kayu,

- Atap konstruksi rangka kuda-kuda kayu,

- Penutup konstruksi Asbes/seng gelombang kecil.

e. Sanitair minimal untuk RIT-1 sampai dengan RsS-2 minimal memiliki:

- Kloset jongkok kakus beserta leher angsanya 1 unit,

- Bak air mandi fibre/plastik 1 unit,

- Disiapkan instalasi diluar sumber sumur pompa tangan 1 unit.

\section{Konsep Perumahan Berwawasan Lingkungan}

Hal utama yang harus dipertimbangkan dalam perencanaan perumahan adalah manajemen lingkungan yang baik dan terarah, karena lingkungan suatu perumahan merupakan faktor yang sangat menentukan dan keberadaannya tidak boleh diabaikan. Pertimbangan dalam faktor-faktor lingkungan dalam perencanaan lingkungan perumahan mutlak diperlukan karena pada hakikatnya proses terbentuknya lingkungan perumahan 
merupakan akumulasi dari unit-unit rumah sebagai pembentuk perumahan tersebut. Perencanaan terhadap lingkungan perumahan terkait secara makro dan mikro. Wawasan secara mikro merupakan perencanaan secara detail terhadap unit-unit rumah sedangkan secara makro adalah perencanaan dan pencermatan terhadap lingkungan dimana perumahan tersebut berada.

Ada beberapa indikator yang dapat digunakan untuk memastikan perumahan yang ramah lingkungan. Pertama, pemilihan lokasi yang tepat (strategis, aman, bebas banjir, aksesibilitas mudah). Kedua, masalah besar di perkotaan adalah keterbatasan lahan yang boleh dibangun. Ketiga, pengembang harus membangun sistem pengolahan air limbah bersih yang mendaur ulang $100 \%$ air buangan, baik keperluan sehari-hari (cuci tangan, piring, kendaraan, atau bersuci diri) maupun air limbah (air buangan dari kamar mandi, kloset air). Keempat, pencemaran udara dari kendaraan diredam dengan membangun koridor jalur hijau jalan yang lebar dan teduh pepohonan besar yang rindang. Kelima, pengembang mengembangkan ekodrainase yang bertujuan menyerapkan air permukaan sebanyakbanyaknya ke dalam tanah. Keenam, masalah sampah diselesaikan dengan membangun tempat proses pengolahan dan pengelolaan sampah secara berkelanjutan dengan prinsip zero waste material, melalui Program 3R (reduce, reuse, recycle). Ketujuh, beragam desain arsitektur perumahan yang sesuai dengan selera calon penghuni dan keselarasan antar bangunan menyatu dengan lingkungan sekitar (Joga, 2007, Permenpera, 2008 dan dari berbagai sumber).

\section{Importance Performance Analysis (IPA)}

IPA digunakan untuk analisis tingkat kinerja pelayanan. Data yang digunakan untuk analisis ini adalah hasil kuisioner persepsi masyarakat terhadap kinerja suatu pelayanan berdasarkan indikator penilaian yang telah ditetapkan. Dalam analisis ini akan digunakan variabel $\mathrm{X}$ untuk menunjukkan tingkat kinerja dan variabel $\mathrm{Y}$ untuk kepentingan indikator. Dengan $n$ adalah jumlah responden.

$\bar{x}=\frac{\sum \bar{x}}{k} \mathrm{dan}_{\bar{y}}=\frac{\sum \bar{y}}{k}$

Dengan $k$ adalah jumlah indikator.

Diagram kartesius tersebut disajikan pada Gambar 1. Pengertian kuadran pada Gambar 1 adalah:

1. Kuadran A menunjukkan indikator yang kondisinya tidak memuaskan dan perlu mendapatkan prioritas peningkatan.

2. Kuadran B menunjukkan indikator yang kondisinya telah memenuhi harapan dan perlu dipertahankan.

3. Kuadran $\mathrm{C}$ menunjukkan indikator tidak memuaskan tetapi juga tidak begitu penting.

4. Kuadran D tidak begitu penting, tingkat kepuasan dilakukan dengan baik, tetapi indikator tidak terlalu penting

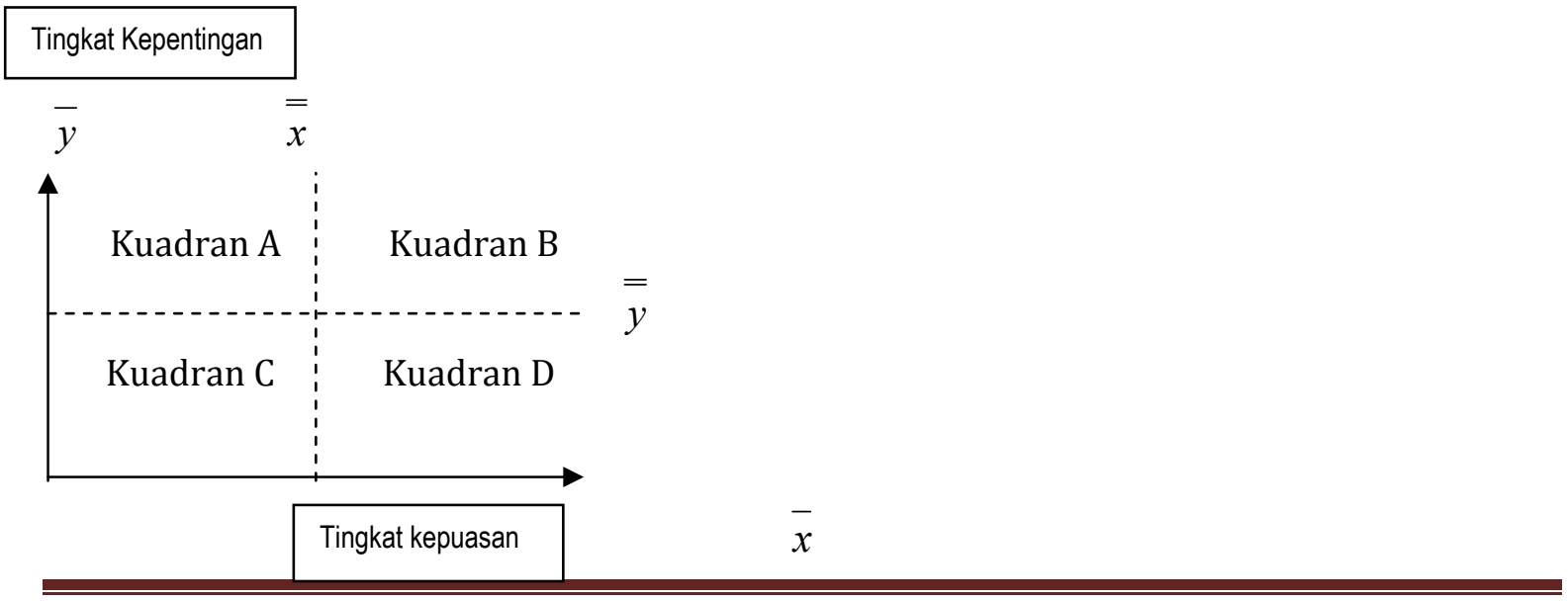




\section{Gambar 1 Diagram Kartesius}

Dalam metode ini langkah-langkah yang dilakukan dalam analisa IPA adalah sebagai berikut:

1. Responden diminta menilai indikator berdasarkan tingkat kepentingan setiap indikator.

2. Responden yang sama diminta untuk menilai indikator berdasarkan kepuasan setiap indikator.

3. Mencari rata-rata data responden dari setiap indikatornya, baik berdasarkan kepentingan maupun kepuasan.

4. Mencari rata-rata data responden yang didapat dari setiap individu, berdasarkan kepentingan maupun kepuasan.

5. Mem-plot data rata-rata aspek yang didapat berdasarkan kepuasan dan kepentingan pada diagram kartesius, untuk mendapatkan garis $\overline{\bar{X}}$, yaitu garis skor rata-rata tingkat kepuasan dan $\overline{\bar{Y}}$, yaitu garis skor rata-rata tingkat kepentingan.

6. Mem-plot data rata-rata indikator yang didapat berdasarkan kepuasan dan kepentingan, untuk mengetahui letak indikator pada kuadran A, B, C atau D.

\section{METODE PENELITIAN} Alir Penelitian

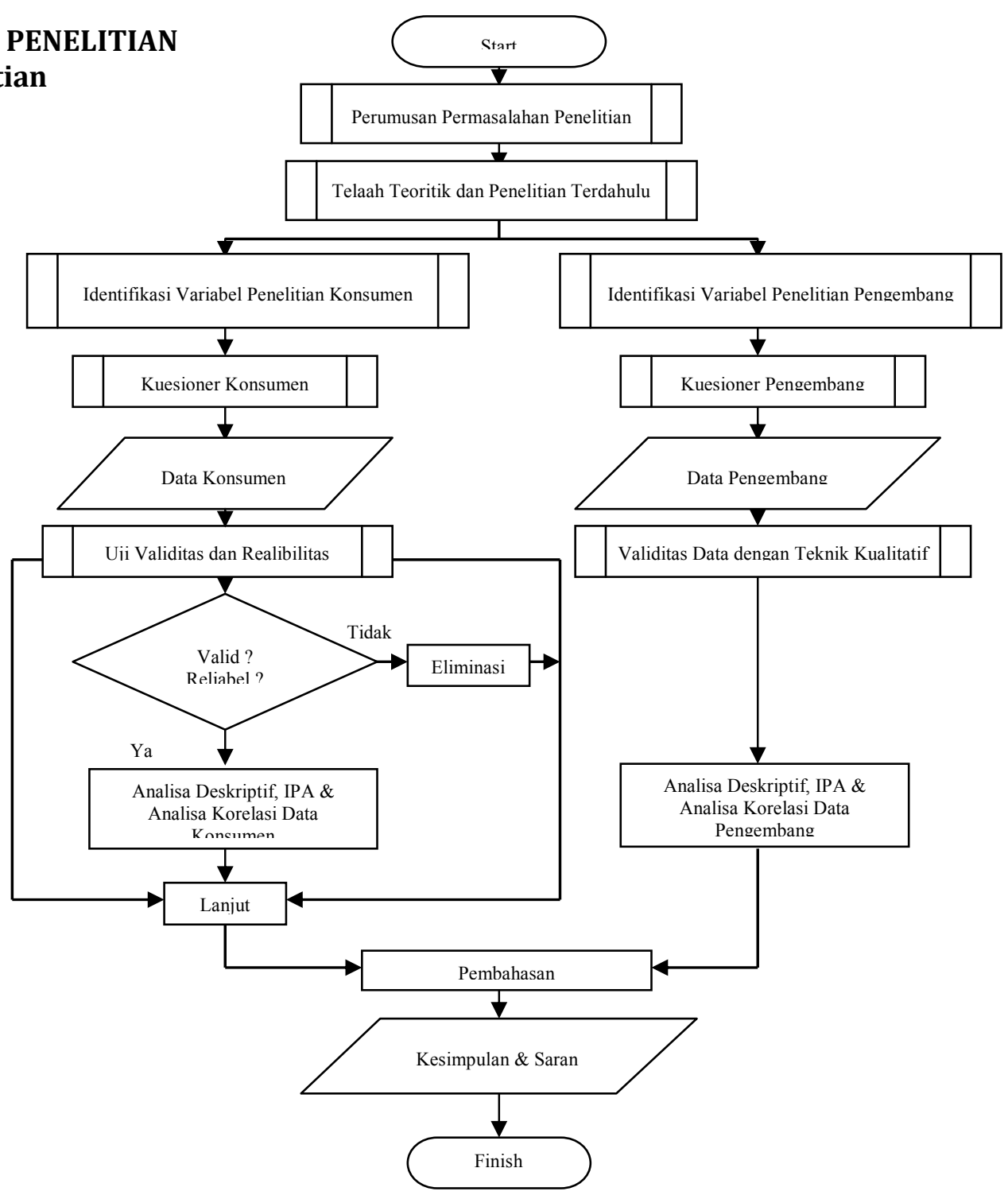




\section{Kerangka Pikir Penelitian}

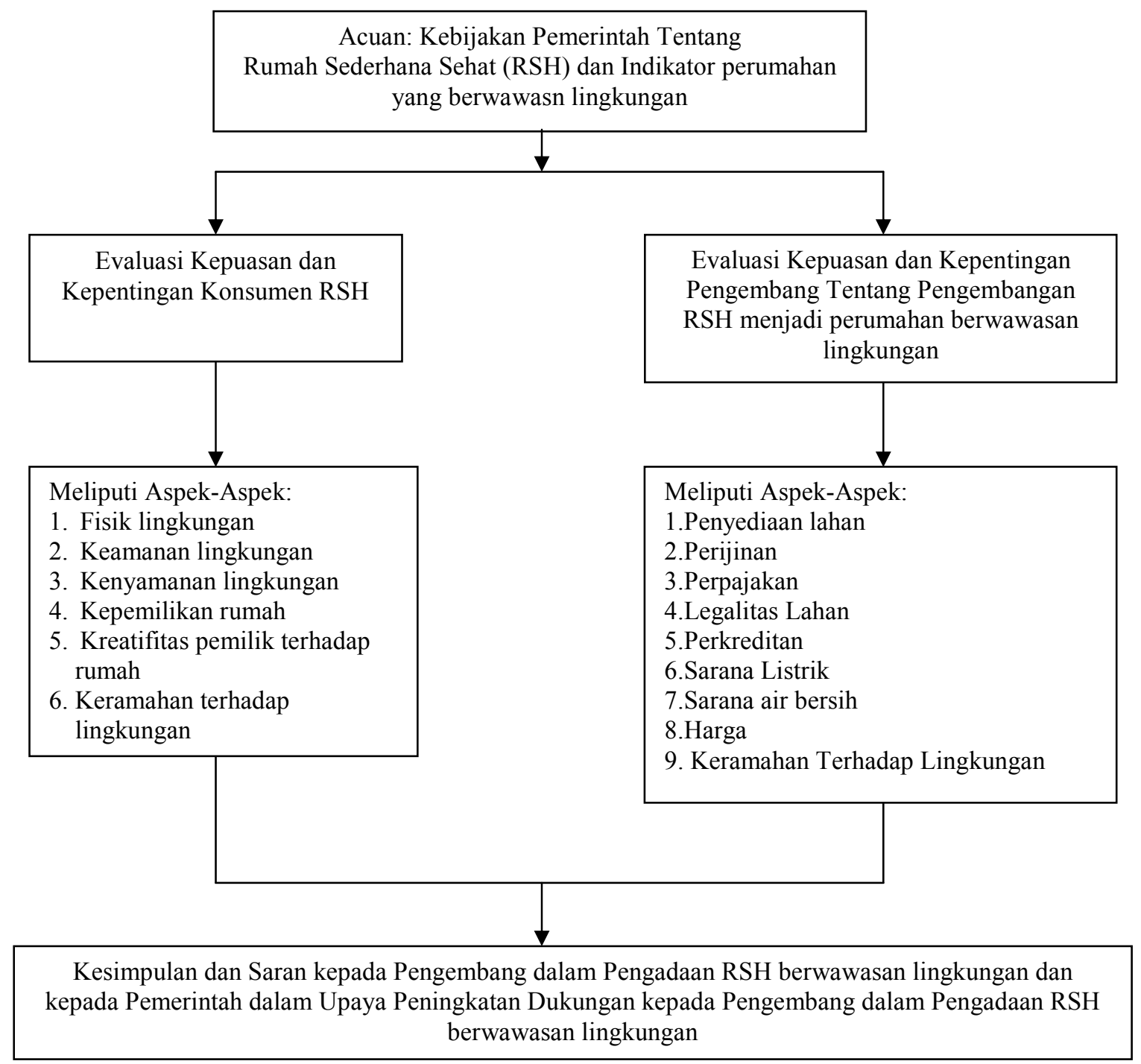

Gambar 3 Kerangka Pikir Penelitian

\section{Data Yang Diperlukan}

Data yang digunakan dalam studi ini adalah data primer, yang diperoleh dari pengamatan langsung di lapangan dan data sekunder, yang diperoleh dari instansi terkait, antara lain :

1. Data Primer

Data primer berupa pendapat/persepsi dari para pengembang (developer) dan konsumen di Wilayah Kabupaten Malang mengenai perumahan RSH yang berwawasan lingkungan. Data dari responden pengembang berupa kepuasan pengembang terhadap RSH yang dikembangkan menjadi perumahan yang berwawasan lingkungan dan data dari responden konsumen berupa kepuasan konsumen RSH terhadap RSH yang dikembangkan menjadi perumahan yang berwawasan lingkungan.

2. Data Sekunder 
- Kebijakan pengembangan wilayah dan RTRW Kabupaten Malang yang bersumber dari Bappeda Kabupaten Malang.

- Kebijakan yang mengatur tentang perumahan di Kabupaten Malang.

- Kabupaten Malang dalam Angka yang bersumber dari BPS Kabupaten Malang.

- Data tentang jumlah rumah, jumlah penghuni dan jumlah fasilitas pada perumahan yang dijadikan objek penelitian.

- Data kependudukan kabupaten Malang yang bersumber dari kantor kelurahan dan kecamatan serta Badan Pusat Statistik Kabupaten Malang.

- Daftar harga satuan upah, bahan dan alat konstruksi di Kabupaten Malang.

\section{HASIL DAN PEMBAHASAN}

\section{Kondisi Umum RSH di Kabupaten Malang}

Perumahan Taman Tambak Asri Permai, Singosari Residence, Perumahan Mondoroko Raya, Malang Anggun Sejahtera, Griya Permata Alam, Graha Permata Alam, Perumahan Gadang Cahaya di Kabupaten Malang. Perumahan-perumahan tersebut merupakan perumahan Rumah Sederhana Sehat (RSH). Sampai saat ini pembangunan RSH masih berlangsung dan pada saat penelitian, RSH dengan tipe 36 telah terbangun sebanyak 3.010 unit.

\section{Pengembangan Rumah Sederhana Sehat Menjadi Berwawasan Lingkungan}

Hal utama yang harus dipertimbangkan dalam perencanaan perumahan adalah manajemen lingkungan yang baik dan terarah, karena lingkungan suatu perumahan merupakan faktor yang sangat menentukan dan keberadaannya tidak boleh diabaikan. Pertimbangan dalam faktor-faktor lingkungan dalam perencanaan lingkungan perumahan mutlak diperlukan karena pada hakikatnya proses terbentuknya lingkungan perumahan merupakan akumulasi dari unit-unit rumah sebagai pembentuk perumahan tersebut. Perencanaan terhadap lingkungan perumahan terkait secara makro dan mikro. Wawasan secara mikro merupakan perencanaan secara detail terhadap unit-unit rumah sedangkan secara makro adalah perencanaan dan pencermatan terhadap lingkungan dimana perumahan tersebut berada.

Ada beberapa indikator yang dapat digunakan untuk memastikan perumahan yang ramah lingkungan. Pertama, pemilihan lokasi yang tepat (strategis, aman, bebas banjir, aksesibilitas mudah). Kedua, masalah besar di perkotaan adalah keterbatasan lahan yang boleh dibangun. Ketiga, pengembang harus membangun sistem pengolahan air limbah bersih yang mendaur ulang $100 \%$ air buangan, baik keperluan sehari-hari (cuci tangan, piring, kendaraan, atau bersuci diri) maupun air limbah (air buangan dari kamar mandi, kloset air). Keempat, pencemaran udara dari kendaraan diredam dengan membangun koridor jalur hijau jalan yang lebar dan teduh pepohonan besar yang rindang. Kelima, pengembang mengembangkan ekodrainase dan biopori yang bertujuan menyerapkan air permukaan sebanyak-banyaknya ke dalam tanah. Keenam, masalah sampah diselesaikan dengan membangun tempat proses pengolahan dan pengelolaan sampah secara berkelanjutan dengan prinsip zero waste material, melalui Program 3R (reduce, reuse, recycle). Ketujuh, beragam desain arsitektur perumahan yang sesuai dengan selera calon penghuni dan keselarasan antar bangunan menyatu dengan lingkungan sekitar.

Dari beberapa indikator diatas tidak semua dapat diaplikasikan kedalam rancangan rumah sederhana sehat. Beberapa indikator yang dapat di terapkan adalah:

1. Perancangan sistem daur ulang limbah rumah tangga sebelum dibuang ke saluran pembuangan pemukiman.

2. Perancangan tempat resapan air di lingkungan bangunan atau mengembangkan ekodrainase dan biopori yang bertujuan menyerapkan air permukaan sebanyakbanyaknya ke dalam tanah. 
3. Perancangan koridor jalur hijau jalan yang lebar dan teduh pepohonan besar yang rindang guna meredam pencemaran udara.

4. Perancangan desain arsitektur perumahan yang sesuai dengan selera calon penghuni dan keselarasan antar bangunan menyatu dengan lingkungan sekitar.

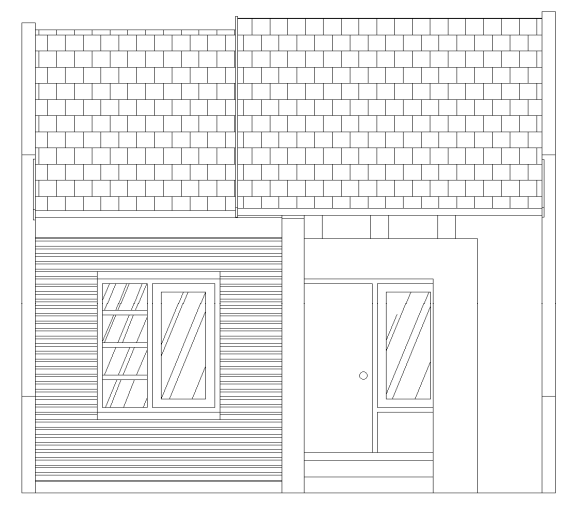

TAMPAK DEPAN

Gambar 4 Tampak Depan RSH

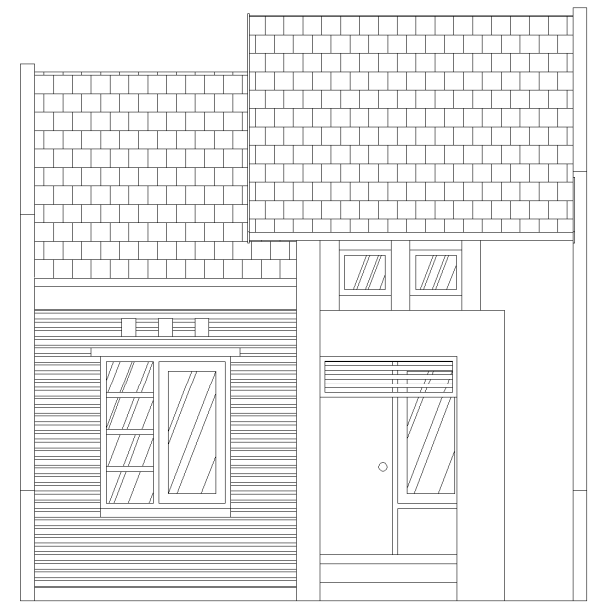

TAMPAK DEPAN PENGEMBANGAN

Gambar 5 Tampak Depan RSH Berwawasan Lingkungan 


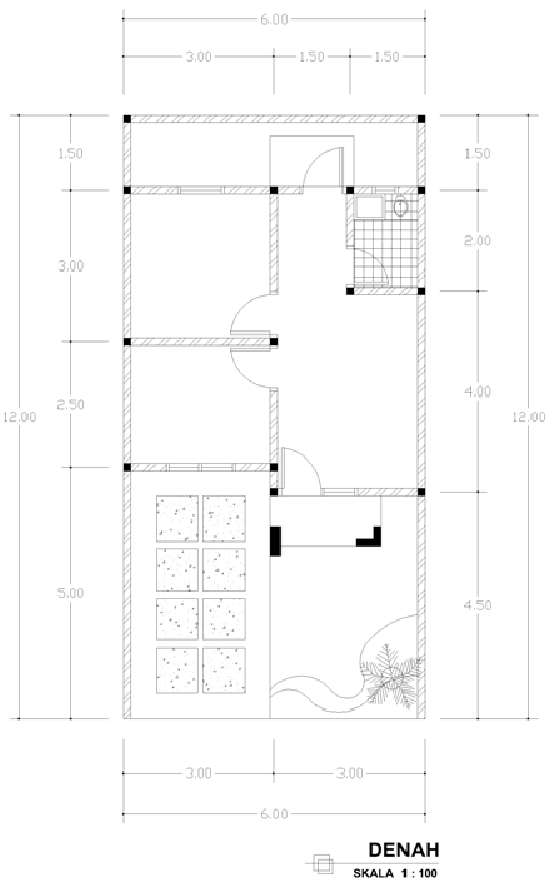

Gambar 6 Denah Rumah Sederhana Sehat

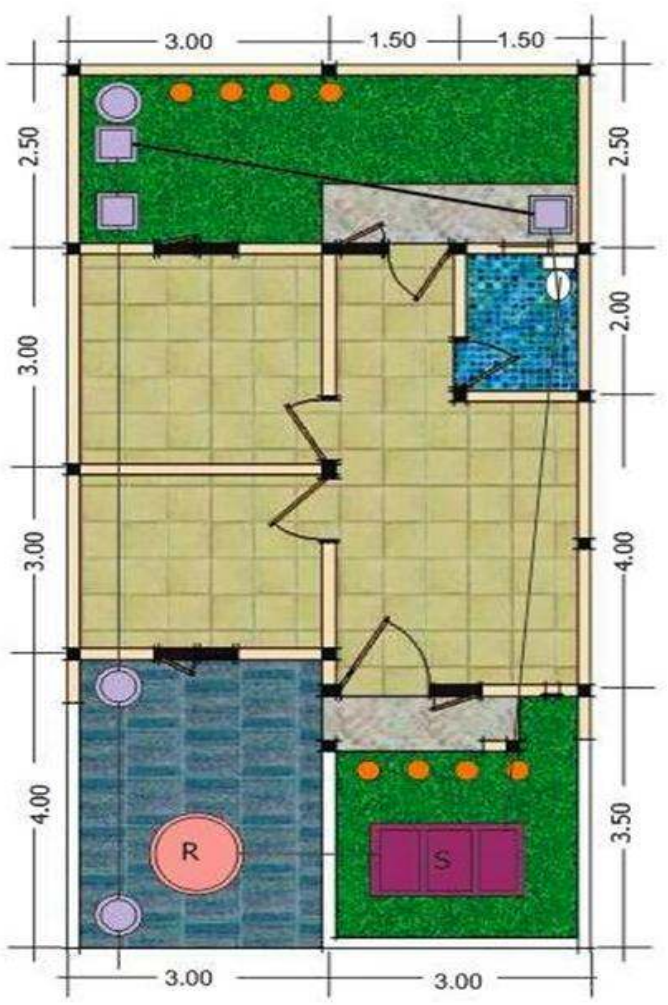

Gambar 7 Denah dan Sanitasi Rumah Sehat Berwawasan Lingkungan

\section{Rencana Anggaran Biaya}

Keputusan Menteri Keuangan Republik Indonesia Nomor 197/KMK.03/2007, tentang Perubahan Kedua Atas Keputusan Menteri Keuangan Nomor 524/KMK.03/2007 Tentang Batasan Rumah Sederhana, Rumah Sangat Sederhana, Rumah Susun Sederhana, Pondok Boro, 
Asrama Mahasiswa, dan Pelajar Serta Perumahan Lainnya yang Atas Penyerahannya Dibebaskan Dari Pengenaan Pajak Pertambahan Nilai.

Kebijakan Tentang Pajak Pertambahan Nilai (PPN) diantaranya adalah:

- Rumah Sederhana dan Rumah Sangat Sederhana (tipe 21, 27 dan 36) yang perolehannya dibiayai melalui fasilitas kredit pemilikan bersubsidi penyerahannya dibebaskan dari pengenaan PPN.

- Rumah Sederhana dan Rumah Sangat Sederhana adalah Rumah Sederhana Sehat (RSH) yang perolehannya dibiayai fasilitas kredit bersubsidi maupun tidak bersubsidi dengan harga jual tidak melebihi Rp.55.000.000,00 (lima puluh lima juta rupiah).

Sebagai contoh rumah sederhana sehat sebelum pengembangan pada rumah type 36/72 pada perumahan Malang Anggun Sejahtera sebesar Rp 38.257.859. Jumlah tersebut belum termasuk harga tanah. Dengan adanya pengembangan berwawasan lingkungan maka diperoleh rencana anggaran biaya $\mathrm{Rp} 41.434 .093$ dan harga tersebut belum termasuk harga tanah. Dapat kita ketahui bahwa terjadi peningkatan anggaran biaya sebesar Rp 3.176.234.

\section{Deskripsi Frekuensi Keinginan Konsumen RSH}

Analisis ini menggunakan tabel distribusi frekuensi tanggapan responden terhadap aspek-aspek keinginan konsumen RSH. Terdapat 7 aspek yang diukur pada keinginan konsumen, yakni: Aspek Fisik Lingkungan (X1), Aspek Aspek Komposisi Lingkungan (X2), Aspek Pencemaran Udara dan Lingkungan (X3), Aspek Sistem Pengolahan Air Limbah Bersih yang Mendaur Ulang Air Buangan (X4), Aspek Kretifitas Pemilik Rumah (X5), Aspek Ekodrainase (X6) dan Aspek Kepemilikan Rumah (X7). Secara umum deskripsi keinginan konsumen dikemukakan pada tabel dan diagram berikut:

Tabel 1 Aspek-Aspek Keinginan Konsumen RSH

\begin{tabular}{|c|c|c|c|c|c|c|c|c|c|c|c|c|}
\hline \multirow{2}{*}{ Kategori } & \multicolumn{3}{|c|}{1} & \multicolumn{2}{|c|}{2} & \multicolumn{3}{|c|}{3} & \multicolumn{3}{|c|}{4} & \multicolumn{3}{|c|}{5} & \multicolumn{2}{|c|}{ Jumlah } \\
\cline { 2 - 16 } & F & $\%$ & F & $\%$ & F & $\%$ & F & $\%$ & F & $\%$ & F & $\%$ \\
\hline X1 & - & - & 18 & 10,0 & 136 & 75,6 & 26 & 14,4 & - & - & 180 & 100 \\
\hline X2 & - & - & 32 & 17,8 & 118 & 65,6 & 30 & 16,7 & - & - & 180 & 100 \\
\hline X3 & - & - & 1 & 0,6 & 111 & 61,7 & 65 & 36,1 & 3 & 1,7 & 180 & 100 \\
\hline X4 & - & - & 1 & 0,6 & 44 & 24,4 & 135 & 75 & - & - & 180 & 100 \\
X5 & - & - & 33 & 18,3 & 88 & 48,9 & 58 & 32,2 & 1 & 0,6 & 180 & 100 \\
\hline X6 & - & - & 1 & 0,6 & 44 & 24,4 & 135 & 75 & - & - & 180 & 100 \\
\hline X7 & - & - & 1 & 0,6 & 76 & 42,2 & 101 & 56,1 & 2 & 1,1 & 180 & 100 \\
\hline
\end{tabular}

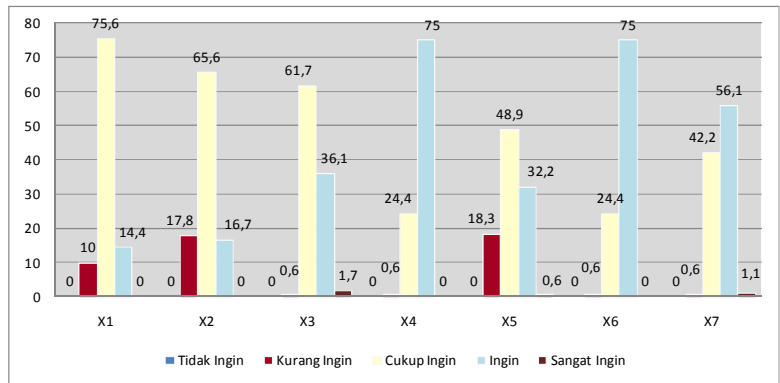

Gambar 8 Aspek-Aspek Keinginan Konsumen RSH

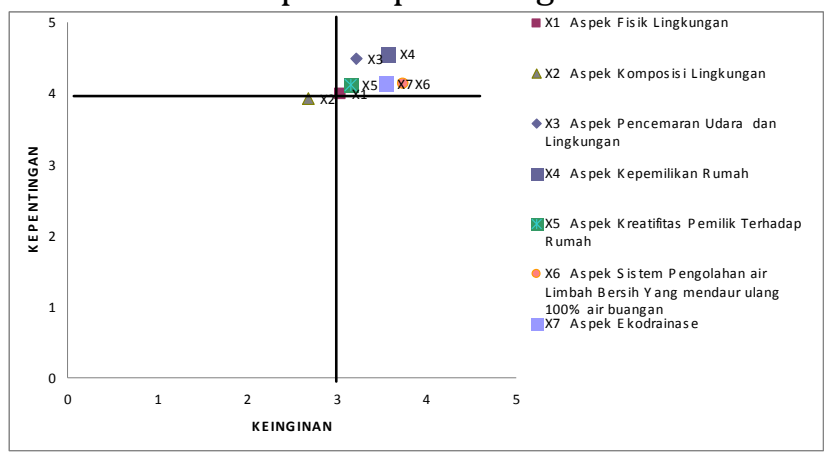

Gambar 9 IPA : Aspek- Aspek Keinginan Konsumen 


\section{Deskripsi Aspek Tingkat Kepentingan Konsumen RSH}

Tingkat konsumen RSH diukur dari 7 aspek yakni fisik lingkungan, komposisi lingkungan, pencemaran udara dan lingkungan, sistem pengolahan air limbah bersih yang mendaur ulang $100 \%$ air buangan, kreatifitas pemilik terhadap rumah, ekodrainase, kepemilikan rumah. Secara umum deskripsi keinginan konsumen dikemukakan pada tabel dan diagram berikut:

Tabel 2 Aspek-Aspek Tingkat Konsumen RSH

\begin{tabular}{|c|c|c|c|c|c|c|c|c|c|c|c|c|}
\hline \multirow{2}{*}{ Kategori } & \multicolumn{2}{|c|}{1} & \multicolumn{2}{|c|}{2} & \multicolumn{3}{|c|}{3} & \multicolumn{3}{|c|}{4} & \multicolumn{3}{|c|}{5} & \multicolumn{2}{|c|}{ Jumlah } \\
\cline { 2 - 14 } & F & $\%$ & F & $\%$ & F & $\%$ & F & $\%$ & F & $\%$ & F & $\%$ \\
\hline X1 & - & - & - & - & 12 & 6,7 & 157 & 87,2 & 11 & 6,1 & 180 & 100 \\
\hline X2 & - & - & 1 & 0,6 & 40 & 22,2 & 109 & 60,6 & 30 & 16,7 & 180 & 100 \\
X3 & - & - & - & - & 8 & 4,4 & 75 & 41,7 & 97 & 53,9 & 180 & 100 \\
\hline X4 & - & - & 1 & 0,6 & 26 & 14,4 & 100 & 55,6 & 53 & 29,4 & 180 & 100 \\
\hline X5 & - & - & 1 & 0,6 & 15 & 8,3 & 125 & 69,4 & 39 & 21,7 & 180 & 100 \\
\hline X6 & - & - & - & - & 10 & 5,6 & 136 & 75,6 & 34 & 18,9 & 180 & 100 \\
\hline X7 & - & - & - & - & 7 & 3,9 & 67 & 37,2 & 106 & 58,9 & 180 & 100 \\
\hline
\end{tabular}

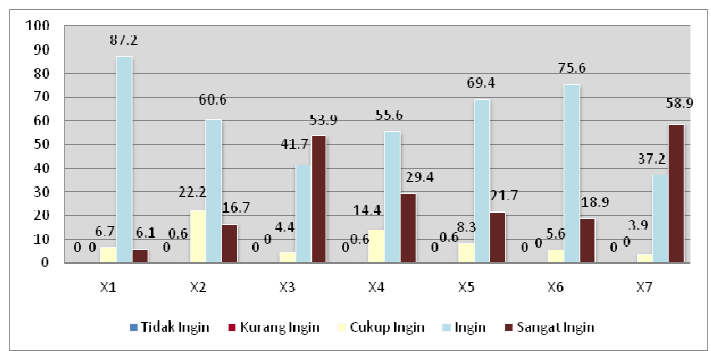

Gambar 10 Aspek-Aspek Tingkat Kepentingan Konsumen RSH

\section{Deskripsi Frekuensi Keinginan Pengembang tentang Dukungan Pemerintah Terhadap Pengadaan RSH}

Ada 8 aspek yang diukur pada pengembang tentang dukungan pemerintah terhadap pengadaan RSH, yakni: Aspek Penyediaan Lahan (X1), Aspek Perijinan (X2), Aspek Perpajakan (X3), Aspek Legalitas Lahan (X4), Aspek Perkreditan (X5), Aspek Sarana Listrik (X6), Aspek Sarana Air Bersih (X7), dan Aspek Harga (X8). Secara umum deskripsi keinginan pengembang terhadap dukungan pemerintah dalam pengadaan RSH dikemukakan pada tabel dan diagram berikut:

Tabel 3 Aspek-Aspek Keinginan Pengembang Terhadap Dukungan Pemerintah Dalam Pengadaan RSH
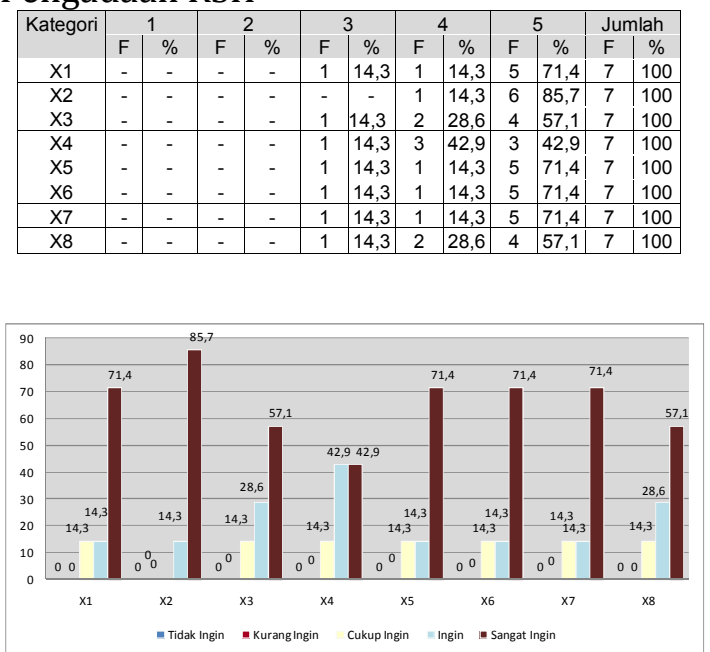

Gambar 11 Aspek-Aspek Keinginan Pengembang Terhadap Dukungan Pemerintah Dalam Pengadaan RSH 


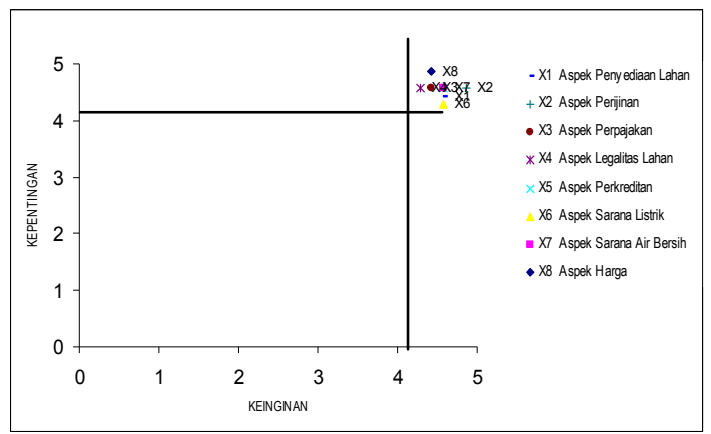

Gambar 12 IPA : Aspek Keinginan Pengembang Terhadap Dukungan Pemerintah Dalam Pengadaan RSH

\section{Deskripsi Frekuensi Tingkat Kepentingan Pengembang tentang Dukungan Pemerintah Terhadap Pengadaan RSH}

Ada 8 aspek yang diukur pada pengembang tentang dukungan pemerintah terhadap pengadaan RSH, yakni: Aspek Penyediaan Lahan (X1), Aspek Perijinan (X2), Aspek Perpajakan (X3), Aspek Legalitas Lahan (X4), Aspek Perkreditan (X5), Aspek Sarana Listrik (X6), Aspek Sarana Air Bersih (X7), dan Aspek Harga (X8). Secara umum deskripsi Tingkat kepentingan pengembang terhadap dukungan pemerintah dalam pengadaan RSH dikemukakan pada tabel dan diagram berikut :

4 Aspek-Aspek Keinginan Pengembang Terhadap Dukungan Pemerintah Dalam Pengadaan $\mathrm{RSH}$

\begin{tabular}{|c|c|c|c|c|c|c|c|c|c|c|c|c|}
\hline \multirow[t]{2}{*}{ Kategori } & \multicolumn{2}{|c|}{1} & \multicolumn{2}{|c|}{2} & \multicolumn{2}{|c|}{3} & \multicolumn{2}{|c|}{4} & \multicolumn{2}{|c|}{5} & \multicolumn{2}{|c|}{ Jumlah } \\
\hline & $F$ & $\%$ & $F$ & $\%$ & $F$ & $\%$ & $\mathrm{~F}$ & $\%$ & $F$ & $\%$ & $\mathrm{~F}$ & \\
\hline $\mathrm{X} 1$ & - & 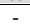 & & - & 1 & 14,3 & 2 & 28,6 & 4 & 57,1 & 7 & 100 \\
\hline $\mathrm{X} 2$ & & - & & & & 14,3 & & 14,3 & 5 & 71,4 & 7 & 100 \\
\hline $\mathrm{X3}$ & & - & - & - & 1 & 14,3 & 1 & 14,3 & 5 & 71,4 & 7 & 100 \\
\hline$x$ & & & & - & & 14,3 & & 14,3 & 5 & 71,4 & 7 & 10 \\
\hline$X 5$ & & - & - & - & 1 & 14,3 & 1 & 14,3 & 5 & 71,4 & 7 & 10 \\
\hline$x$ & - & - & - & - & 1 & 14,3 & 3 & 42,9 & 3 & 42,9 & 7 & 10 \\
\hline$x$ & - & - & - & - & 1 & 14,3 & & 14,3 & 5 & 71,4 & 7 & 100 \\
\hline $\mathrm{X} 8$ & & - & - & - & & & 1 & 14,3 & 6 & 85,7 & 7 & 100 \\
\hline
\end{tabular}

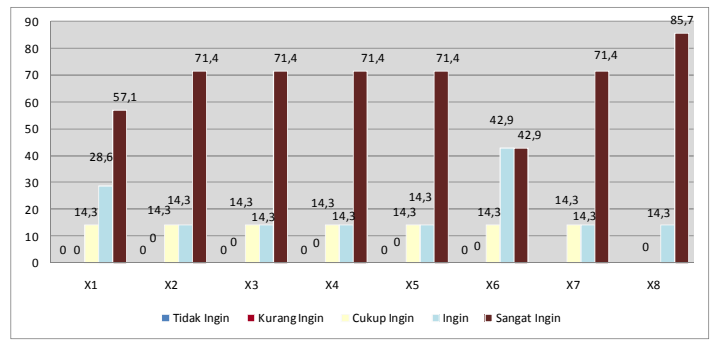

Gambar 12 Aspek-Aspek Tingkat Kepentingan Pengembang Tentang Dukungan Pemerintah Dalam Pengadaan RSH

\section{KESIMPULAN}

Berdasarkan hasil analisa data dan perhitungan maka sesuai dengan rumusan masalah, dihasilkan beberapa kesimpulan sebagai berikut :

1. Perancangan RSH yang berwawasan lingkungan dilakukan dengan mengembangkan desain RSH yang telah ada menjadi RSH yang berwawasan lingkungan, yaitu dengan beberapa cara berikut :

$\checkmark$ Membuat sistem daur ulang limbah rumah tangga sebelum dibuang ke saluran pembuangan pemukiman dilakukan dengan merancang sistem pembuangan yang terencana. 
$\checkmark$ Membuat tempat resapan air di lingkungan bangunan atau mengembangkan ekodrainase dan biopori yang bertujuan menyerapkan air permukaan sebanyakbanyaknya ke dalam tanah.

$\checkmark \quad$ Membuat koridor jalur hijau jalan yang lebar dan teduh, serta pepohonan besar yang rindang guna meredam pencemaran udara di lingkungan perumahan.

$\checkmark$ Merencanakan desain arsitektur perumahan yang sesuai dengan selera calon penghuni dan keselarasan antar bangunan menyatu dengan lingkungan sekitar misalnya penggunaan konstruksi rangka baja ringan pada atap rumah.

2. Nilai jual RSH berwawasan lingkungan di bandingkan dengan RSH yang ada telah mengalami peningkatan nilai jual sebesar Rp. 3.090.389.,-. Hal tersebut dapat diketahui dari Rencana Anggaran Biaya (RAB) sebelum dan sesudah RSH, dikembangkan menjadi RSH yang berwawasan lingkungan. Besarnya nilai jual RSH yang ada (kondisi eksisting) sebesar Rp. 37.223.863,-. Sedangkan RSH berwawasan lingkungan memiliki nilai jual sebesar Rp. 40.314.253,-.

3. Tingkat keinginan konsumen terhadap RSH yang dikembangkan menjadi RSH yang berwawasan lingkungan yaitu $0,6 \%$ responden menyatakan kurang ingin; $24,4 \%$ menyatakan cukup ingin dan $75 \%$ menyatakan ingin.

\section{SARAN}

1. Saran buat kontraktor/pengembang

Sebaiknya pengembang dalam memilih lokasi perumahan walaupun berada dipinggir kota, harus tetap mempertimbangkan lokasi perumahan dekat dengan sarana pendidikan dan kesehatan. Sedangkan mengenai Keamanan Lingkungan, Kenyamanan Lingkungan, Kepemilikan Rumah dan Kreatifitas Pemilik Terhadap Rumah, bisa dikatakan telah memuaskan konsumen, diharapkan pengembang dapat mempertahankan kepuasan konsumen pada aspek-aspek ini

2. Saran buat pemerintah

Menyediakan bank tanah, artinya pemerintah menyediakan lahan khusus yang diperuntukan bagi RSH. Tetapi apabila pemerintah mengalami kesulitan dalm merealisasikannya, maka pemerintah pada masa mendatang hendaknya mengarahkan pembangunan rumah susun sederhana sewa murah, karena pembanguna rumah susun tidak memerlukan lahan yang luas, sehingga biaya tanah dapat dikurangi. Menekan mahalnya biaya perijinan yang jauh diatas harga resmi dan pola birokrasi yang berbelitbelit.

Mensosialisikan keputusan-keputusannya dengan baik, agar program pemerintah dalam pengadaan RSH bisa berjalan sesuai dengan yang diharapkan. Pemerintah telah mengeluarkan kebijakan tentang bebas pajak BPHTB bagi RSH, walaupun keputusan tersebut telah diterbitkan dari bulan Oktober tahun 2006, tetapi pihak-pihak terkait, yaitu pengembang dan bank penyedia KPR banyak yang belum mengetahuinya.

Perlu adanya penerbitan Inpres soal percepatan pembangunan perumahan RSH, yang didalamnya tidak hanya dari Menteri Negara Perumahan Rakyat saja, tetapi perlu komitmen kepala daerah dan harus mengkoordinir berbagai masukan dari menteri kabinet karena RSH berhubungan langsung dengan BPN, PLN dan BTN.

\section{DAFTAR PUSTAKA}

Anonimus. 1996. An Urbanizing World - Global Report on Human Settlement, Habitat II Conference, United Nations Centre for Human Settlements, Istambul, Turkey.

Anonimus. 2004. Rencana Aksi Gerakan Nasional Pengembangan Satu Juta Rumah Serta Percepatan Penyediaan Air Minum dan Sanitasi untuk Masyarakat Berpenghasilan Rendah Tahun 2004-2020, Departemen Permukiman dan Prasarana Wilayah, Jakarta.

Anonimus. 2006. Tim Indonesia Bangkit, Biro Pusat Statistik, Jakarta. 
Hernowo, M, Membangun Rumah Sederhana Sehat (RSH) Pekerjaan yang Makin Berat. Situs Harian Utama Kompas, www.kompas.com / kompas-cetak / 0501 / 08 / rumah / 1484953.htm. 8 Januari 2005.

Maslow, A. H. 1993 Motivasi dan Kepribadian 2 - Teori Motivasi Dengan Pendekatan Hierarki Kebutuhan Manusia, Cetakan Kedua, PT. Pustaka Binaman Pressindo, Jakarta.

Miles, M. E. et. al. 1995. Real Estate Development Principles and Process, The Urban Land Institute, Washington DC, USA.

---------Menteri Pekerjaan Umum Republik Indonesia. Pidato Kebijakan Rencana Tata Ruang Untuk Mendukung Rumah Sederhana Sehat (RSH) pada Musyawarah Konsultasi 2005 Rumah Sederhana Sehat (RSH) dan Pembangunan Daerah Tertinggal (PDT), Jakarta. 19 September 2005.

Moleong, Lexy J. 1990. Metodologi Penelitian Kualitatif, PT. Remaja Rosdakarya, Bandung.

Newmark, N. L. and Thompson P. J. 1977. Self, Space and Shelter - An Introduction to Housing, Gansfield Press, San Fransisco, USA.

--------Peraturan Menteri Keuangan Nomor 86/PMK.03/2006, Tentang Cara Penetuan Besarnya Nilai Perolehan Obyek Pajak Tidak Kena Pajak Bea Perolehan Hak Atas Tanah dan Bangunan. Jakarta.

-------Peraturan Menteri Negara Perumahan Rakyat Nomor 01/PERMEN/M/2005, Tentang Pengadaan Perumahan dan Permukiman dengan Dukungan Fasilitas Subsidi Perumahan melalui KPR/KPRS Bersubsidi, Kementerian Negara Perumahan Rakyat, Jakarta.Subroto, 1992. Fungsi Rumah sebagai Tempat Pemenuhan Kebutuhan Hidup Manusia, Edisi Kedua. Rineka Cipta, Jakarta.

---------Peraturan Pemerintah Republik Indonesia Nomor 80 Tahun 1999, Tentang Kawasan Siap Bangun dan Lingkungan Siap Bangun yang Berdiri Sendiri, Jakarta.

Richard P.J. and M.D. Leonor. 1982. Target Setting for Basic Needs, International Labour Office, Geneve, Switzerland.

Riduwan. 2005. Rumus dan Data dalam Aplikasi Statistika, Alfabeta, Bandung.

Silas, J. 1997. Peremajaan Perumahan dan Permukiman Kota : Strategi, Masalah dan Tantangannya, Majalah Properti.

---------Surat Keputusan Dirjen Perumahan dan Permukiman No. 06/KPTS/DM/2004, Tentang Standar Operasional dan Prosedur Pelaksanaan Program Bantuan Perumahan melalui Fasilitas Kredit Perumahan Bersubsidi. Jakarta.

---------Surat Keputusan Menteri Kesehatan Nomor 829/MENKES/SK/VII/1999, Tentang Persyaratan Kesehatan Perumahan, Jakarta.

--------Surat Keputusan Menteri Permukiman dan Prasarana Wilayah Nomor 403/KPTS/M/2002, Tentang Pedoman Teknis Pembangunan Rumah Sederhana Sehat (RSH), Departemen Permukiman dan Prasarana Wilayah, Jakarta.

--------Surat Keputusan Menteri Keuangan Nomor 197/KMK.03/2004, Tentang Batasan Rumah Sederhana, Rumah Sangat Sederhana, Rumah Susun Sederhana, Pondok Boro, Asrama Mahasiswa dan Pelajar serta Perumahan lainnya yang atas Penyerahannya dibebaskan dari Pengenaan Pajak Pertambahan Nilai, Departemen Keuangan, Jakarta.

Punter, et al. 1997. The Design Dimension of Planning, www.eclipseresearch.co.uk/crisp/DesignReview99-5.pdf.

Purwaningsih, E. 1982. Pemenuhan Kebutuhan Perumahan di Perumnas Klender - Dalam Kemiskinan dan Kebutuhan Pokok, CV. Rajawali, Jakarta.

Soetjipto, Jojok W. 2000. Studi Analisa Kebijaksanaan KPR-BTN Dalam Pengadaan RSS di Kotamadya Surabaya Dan Sekitarnya, Tesis Program Magister, Bidang Keahlian Manajemen Proyek Konstruksi, Fakultas Teknik Sipil dan Perencanaan, Program Pascasarjana, Institut Teknologi Sepuluh Nopember, Surabaya.Supranto, J. 1997. Pengukuran Tingkat Kepuasan Pelanggan - Untuk Menaikkan Pangsa Pasar, Rineka Cipta, Jakarta.

Supranto, J. 1997. Pengukuran Tingkat Kepuasan Pelanggan - Untuk Menaikkan Pangsa Pasar, Rineka Cipta, Jakarta.

Sudjana, M. A. 1996. Metode Statistika Edisi 6, Tarsito, Bandung. 
Suhariyanto. 2000. Studi Analisa Kebijaksanaan KPR-BTN Dalam Pengadaan RSS di Kotamadya Malang dan Sekitarnya, Tesis Program Magister, Bidang Keahlian Manajemen Proyek Konstruksi, Fakultas Teknik Sipil dan Perencanaan, Program Pascasarjana, Institut Teknologi Sepuluh Nopember, Surabaya.

Turner, J. F. C. and Fitcher. 1973. Housing by People, Pantheon Books. New York, USA.

--------Undang-Undang Republik Indonesia, Nomor 04, Tahun 1992, Tentang Perumahan dan Permukiman, Jakarta.

Wahyu, Kukur J. 2000. Kajian Terhadap Renovasi Rumah Sebagai Bagian Terhadap Pemenuhan Kebutuhan Penghuni Pada Lokasi Perumahan di Malang, Tesis Program Magister, Bidang Keahlian Manajemen Proyek Konstruksi, Fakultas Teknik Sipil dan Perencanaan, Program Pascasarjana, Institut Teknologi Sepuluh Nopember, Surabaya.

Zuhri, Syaifuddin. 2001. Pengukuran Layak Huni pada Pengadaan Perumahan Sederhana di Sidoarjo, Tesis Program Magister, Bidang Keahlian Manajemen Proyek Konstruksi, Fakultas Teknik Sipil dan Perencanaan, Program Pascasarjana, Institut Teknologi Sepuluh Nopember, Surabaya. 